\title{
ANALISIS ANTASEDEN REVERSE LOGISTICS CAPABILITIES DAN PENGHEMATAN BIAYA USAHA KECIL DAN MENENGAH DI SURABAYA DAN SEKITARNYA
}

\author{
Febriana Wurjaningrum 1), Tuwanku Aria Auliandri2) \\ 'Fakultas Ekonomi dan Bisnis, Universitas Airlangga \\ email: 71 febriana@gmail.com \\ 2Fakultas Ekonomi dan Bisnis, Universitas Airlangga \\ email: tuwanku@yahoo.com
}

\begin{abstract}
This research is aimed to determine the relation of customer orientation, customer opportunism, resource commitment, contractual agreements, and reverse logistic capabilities as well as the relation of reverse logistic capabilities and reverse logistics cost savings. A statistical analysis method focused on testing hypotheses, path analysis, is used as the method of this research. Samples taken in this research involve both small and medium business enterprises (SMEs) in the areas of retail, manufacturing, handicrafts, and drug sellers (drug stores and pharmacies) located in Surabaya, Malang, Singaraja, and Denpasar. Those respondents, moreover, are directly involved in reverse logistics process as well as interacting with suppliers. The results of this research then show that there is a positive relation between customer orientation and reverse logistic capabilities. It is also known that there is a negative relation between customer opportunism and reverse logistic capabilities although the relation is less significant. Furthermore, there is also a positive relation between resource commitment and reverse logistic capabilities. There is also a positive relation between contractual agreements and reverse logistic capabilities although it is not significant. And, it is also shown that there is a positive relation between reverse logistic capabilities and cost savings. Thus, it may be concluded that all five hypotheses proposed in this research have indeed been proven empirically although there are a few variables showing less significant relations, which means that these variables less affect or impact on reverse logistic capabilities and ultimately on cost savings.
\end{abstract}

Keywords: Customer Orientation, Customer opportunism, Resource Commitment, Contractual Agreements, Reverse logistic capabilities, Reverse Logistics Cost Saving, Small And Medium Business Enterprises

\section{PENDAHULUAN}

Para pelaku bisnis di berbagai bidang bisnis dituntut untuk mampu memanfaatkan sumber daya yang tersedia secara maksimal, termasuk sumber daya internal maupun eksternal di era globalisasi. Hal tersebut bertujuan untuk meningkatkan kinerja perusahaan serta mengoptimalkan biaya yang dikeluarkan untuk memproduksi suatu barang atau jasa. Salah satu tantangan yang harus dihadapi oleh pelaku bisnis untuk dapat terus mengembangkan bisnisnya adalah persaingan yang semakin ketat. Jumlah permintaan para pelanggan semakin meningkat dari waktu ke waktu seiring bertambahnya jumlah penduduk serta kebutuhan yang harus dipenuhi. Dengan meningkatnya permintaan dari pelanggan atas suatu barang atau jasa, perusahaan dituntut untuk berusaha lebih keras dalam memenuhi kebutuhan pelanggan. Dalam upaya untuk memenuhi kebutuhan pelanggan tersebut, perusahaan yang berada dalam bidang bisnis yang sama harus mampu bersaing satu sama lain demi kelangsungan hidup perusahaan.

Dalam upaya memenangkan persaingan dengan para pesaingnya, perusahaan harus memiliki nilai lebih dibandingkan dengan pesaing. Salah satu cara yang dapat digunakan oleh perusahaan untuk menghadapi pesaingnya adalah dengan memiliki keunggulan bersaing. Menurut Porter, keunggulan bersaing adalah kemampuan yang dimiliki oleh suatu perusahaan 


\section{Febriana Wurjaningrum Tuwanku Aria Auliandri}

untuk meraih keuntungan ekonomis diatas laba yang mampu diraih oleh pesaing didalam bidang bisnis yang sama. Oleh karena itu, keunggulan dalam bersaing sudah pasti sangat dibutuhkan oleh perusahaan dalam menghadapi pesaingnya agar dapat terus bertahan didalam pasar yang memiliki persaingan yang ketat.

Sejumlah faktor menghasilkan pertumbuhan ekonomi, dimana logistik adalah faktor yang paling diperhatikan di abad 21 ini. Sudah sekian lama dipercaya bahwa kemampuan supply chain yang superior berada hanya pada beberapa negara di Asia yang lebih berkembang, seperti Singapura dan Hongkong (Easton dan Zhang, 2003; Yen-Chun Jim Wu dan Cheng, 2006). Fokus Asia saat ini adalah pada bagaimana menekan biaya produksi dan potensi masa depan untuk cost reduction kini ada pada logistik dan distribusi.

\section{KAJIAN LITERATUR DAN PEGEMBANGAN HIPOTESIS}

\section{a. Supply Chain Management (SCM)}

Terdapat beberapa perbedaan yang mendasar antara konsep supply chain management denn konsep logistic tradisional. Jika manajemen logistik tradisional lebih mengacu pada aktivitas-aktivitas yang terjadi di dalam batas-batas satu organisasi, supply chain management atau manajemen rantai pasok mengacu pada jaringan perusahaan yang melakukan kerja sama dan mengkoordinasikan tindakan mereka untuk memberikan produk maupun jasa ke pasar. Manajemen logistik tradisional memfokuskan pada aktivitas seperti pengadaan, distribusi, pemeliharaan, dan manajemen persediaan saja. Sedangkan manajemen rantai pasok mencakup aktivitas seperti pemasaran produk, pengembangan produk, keuangan, hingga layanan terhadap konsumen.

Menurut Sunil Chopra dan Peter Meindl (2007) di dalam bukunya yang berjudul Supply Chain Management: Strategy, Planning, and Operations, adapun tujuan yang hendak dicapai di dalam setiap supply chain adalah untuk memaksimalkan nilai keseluruhan guna memenuhi kebutuhan para konsumen. Nilai dari sebuah supply chain menghasilkan perbedaan antara produk akhir yang berguna untuk memenuhi kebutuhan konsumen dan biaya yang dapat ditimbulkan selama aktivitas supply chain dalam tujuannya untuk memenuhi permintaan konsumen. Di dalam kebanyakan supply chain, nilai akan sangat berkaitan dengan supply chain profitability atau biasa dikenal juga sebagai supply chain surplus (surplus rantai pasok), yang merupakan selisih antara jumlah pendapatan yang berasal dari konsumen dan biaya keseluruhan yang timbul selama supply chain berlangsung. Makin tinggi pendapatan yang diterima dan makin rendah biaya yang ditimbulkan maka akan semakin baik.

Supply chain profitability adalah total laba yang dibagikan kepada seluruh bagan atau pihak di dalam supply chain. Semakin tinggi profit atau laba yang dihasilkan dan semakin rendah biaya yang dapat ditimbulkan, maka semakin sukses pula supply chain tersebut. Kesuksesan yang diraih oleh supply chain sebaiknya diukur sebagai keuntungan dari keseluruhan supply chain itu sendiri dan tidak diukur sebagai keuntungan setiap bagan atau pihak secara individual. Ketika sudah memahami apa itu supply chain profitability, maka langkah yang harus diperhatikan selanjutnya adalah sumber pendapatan dan biaya. Untuk setiap supply chain yang ada, hanya terdapat satu sumber utama pendapatan, yaitu konsumen. Sedangkan semua aliran informasi, produk, atau uang dapat menimbulkan biaya di dalam supply chain. Oleh karena itu diperlukan pengelolaan yang tepat sehingga mampu menciptakan efisiensi dan efektivitas yang merupakan kunci dari kesuksesan sebuah supply chain. Untuk mencapai supply chain management yang efektif, diperlukan pengelolaan aset, produk, informasi, dan aliran uang yang baik sehingga mampu memaksimalkan supply chain profitability atau keuntungan rantai pasok.

\section{b. Logistik}

Menurut The Council of Logistics Management, "logistics is the part of the supply chain process that plans, implements, and controls the efficient, effective flow and storage of goods, services, and related information from the point of origin to the point of consumption in order to meet customer's requirement". Dengan kata lain, logistik melibatkan proses perencanaan, implementasi, dan pengendalian agar didapat suatu efisiensi aliran biaya dan keefektifan proses penyimpanan bahan mentah, bahan setengah jadi, barang jadi dan informasi - informasi yang berhubungan, dari asal ke titik konsumsi dengan tujuan memenuhi kebutuhan konsumen. Logistik 


\section{Jurnal Manajemen Teori dan Terapan Tahun 8. No. 3, Desember 2015}

merupakan suatu bagian dari supply chain management yang berfokus pada perpindahan barang dari tempat asal ke tempat tujuan, untuk mencapai kepuasan pelanggan. Tujuan utama dari logistik adalah mengatur siklus sehingga memberikan hasil yang bermanfaat bagi perusahaan, terutama pada efisiensi. Dua hal yang menjadi fokus utama dalam dunia logistik adalah internal logistik dan external logistik. Keduanya mengatur aliran dan penyimpanan material dari satu titik ke titik lain dengan fungsi utama meliputi inventory management, purchasing, transportasi dan distribusi, serta warehousing.

Logistik pada dasarnya berfungsi sebagai suatu sistem yang menyatukan berbagai komponen seperti aliran informasi, mulai dari supplier (pemesanan dan pengiriman), informasi dalam proses produksi (persediaan) atau dalam jasa aliran informasi dalam perusahaan (koordinasi), sampai pada informasi pada konsumen (distribusi baik barang maupun jasa). Dalam usaha mempermudah aliran informasi dan distribusi tersebut, terdapat pengelolaan yang terfokus melalui supply chain management (rantai pasokan) untuk mencapai koneksi dan koordinasi antara proses dari bagian lainnya dalam saluran, contohnya supplier dan konsumen, serta organisasi itu sendiri.

Logistik tidak hanya ada pada perusahaan manufaktur saja, namun juga terdapat pada perusahaan jasa, terutama perusahaan pengantaran yang menjadikan logistik sebagai bisnis utamanya. Adanya perkembangan jasa dalam sistem logistik itu sendiri, manajemen logistik sudah seharusnya menambahkan unsur jasa dalam definisi manajemen logistik karena pada dasarnya saat sekarang ini produk jasa tidak dapat dipisahkan, pengantaran nilai suatu produk kepada konsumen tidak akan terlepas dari jasa yang akan menambah nilai dari produk tersebut. Sehingga logistik merupakan proses perencanaan, implementasi, dan pengontrolan arus yang efisien dan efektif dan penyimpanan dari barang, jasa, dan informasi yang berhubungan dari titik awal sampai pada titik konsumsi yang bertujuan untuk memenuhi kebutuhan konsumen.

\section{c. Reverse Logistics}

Reverse logistics berdasarkan The Council of Logistics Management adalah "the process of planning, implementing and controlling the efficient, cost effecting flow of raw material, inprocess inventory, finished goods and related information from the point off origin for the purpose of recapturing value of proper disposal". Dengan kata lain, reverse logistics adalah proses merencanakan, mengimplementasi dan mengontrol aliran bahan mentah yang mempengaruhi biaya, in-process inventory, barang jadi dan informasi terkait dari titik awal untuk tujuan menangkap kembali nilai dari pembuangan yang pantas, secara efisien. Seperti yang telah dijelaskan sebelumnya, reverse logistics yang merupakan kebalikan dari forward logistics. Didefinisikan sebagai pengelolan yang berkaitan dengan penarikan kembali produk kedalam Supply chain-nya dalam rangka untuk memanfaatkan potensi nilai yang masih ada didalam produk tersebut setelah proses disposed.

Ada dua jenis utama dari supply chain yang berkaitan dengan segala jenis kegiatan distribusi yaitu aliran maju (foward) dan aliran mundur (reverse). Reverse logistics adalah proses perencanaan, implementasi, dan pengendalian secara efisien dan efektif aliran barang (bahan baku, sediaan dalam proses, atau barang jadi) dan informasi yang terkait, dari titik konsumsi balik ke titik asal (Rogers dan Tibben-Lembke, 1999). Sama halnya seperti yang dikemukakan Jayaraman et al, (2003) Reverse Logistics adalah aliran dimana produk atau komponen kembali setelah digunakan untuk tujan perbaikan, daur ulang atau pengerjaan kembali. Di dalam dunia dengan sumber daya terbatas dan fasilitas diposal yang terbatas, recovery atau perbaikan yang dilakukan terhadap produk maupun material adalah kunci yang mendukung populasi dengan tingkat konsumsi yang semakin meningkat (Georgiadis dan Vlachos,2004).

Terdapat dua jenis produk yang mungkin terlibat dalam reverse logistics, yaitu:

1. Barang return, yaitu produk yang tidak tersentuh atau jaramg sekali digunakan, seperti misalnya jika konsumen berubah pikiran setelah pembelian.

2. Produk End-of-Life, yaitu produk yang tidak lagi ingin digunakan oleh konsumen.

Pada tipe pengembalian retur, produk dikembalikan karena gagal memuaskan konsumen. Dalam kasus ini, konsumen diberi pengembalian (refund) berupa uang atau ditukar dengan produk lain. Produk - produk ini harus dikumpulkan kembali dan harus diuji sebelum diintegrasikan ulang ke dalam forward supply chain. Dalam kasus lain, produk telah sedikit 


\section{Febriana Wurjaningrum Tuwanku Aria Auliandri}

digunakan oleh konsumen, sehingga produk harus diperbaharui dan dijual seperti itu, di pasar loak (dengan diskon tinggi) atau dibongkar jika mungkin dan beberapa komponennya diintegrasikan dalam proses manufaktur.

Pada pengembalian produk end of life, produk telah digunakan oleh konsumen dalam beberapa waktu dan tidak dapat digunakan lebih jauh dari keadaannya yang sekarang (Brodin, 2002). Produk - produk ini selain dibuang oleh konsumen, dapat memiliki beberapa nilai ekonomis yang dapat dimunculkan ulang, yang dapat dilakukan dalam berbagai cara.

Pilihan yang paling disukai (salah satu yang mungkin menghasilkan nilai paling banyak) secara umum adalah untuk menggunakan kembali produk tersebut (reuse), baik dengan memperbaikinya atau dengan menjualnya di pasar sekunder. Jika reuse tidak mungkin dilakukan, pilihan selanjutnya adalah remanufaktur, yaitu proses pembongkaran dimana setiap bagiannya dibersihkan, diperbaiki atau diganti, sehingga produk baru yang dipasang ulang dapat bekerja dengan baik. Opsi ketiga adalah recycle sebelum menyembuhkan komponen yang dapat digunakan dari produk.

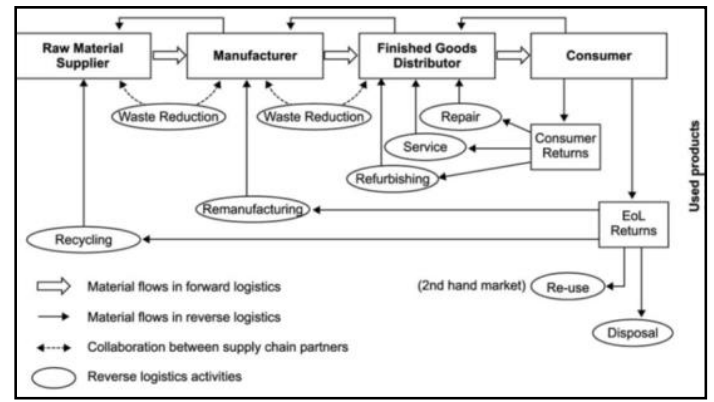

Sumber: Brodin, 2002

\section{Gambar 1. Kegiatan dan Alur Produk dalam Reverse Logistics}

Gambar di atas mengilustrasikan kegiatan dan alur produk dalam reverse logistics mulai dari konsumen sampai dengan produk tersebut dijual kembali.

Reverse logistics telah menjadi kebutuhan kompetitif untuk beberapa alasan termasuk meningkatkan tren pada pengembalian yang dilakukan pelanggan, meningkatkan penggunaan persediaan konsinyasi, mempersingkat siklus hidup produk, dan memperbanyak permintaan pelanggan. Reverse logistics kini semakin dianggap sebagai sebuah proses strategis yang menghasilkan nilai melalui kepuasan pelanggan dan pengendalian biaya. Seiring dengan meningkatnya volume pengembalian secara global, perusahaan tak lagi dapat mengabaikan arus balik dari produk. Dalam konteks ritel, reverse logistics melibatkan proses penanganan dan disposisi barang yang dikembalikan dari pelanggan. Sejalan dengan menyempitnya margin ritel, reverse logistics telah menjadi perhatian utama bagi manajer ritel mengingat komponen biaya penyimpanan, kehilangan penjualan saat ini, nilai produk potensial yang dapat dipulihkan, dan pentingnya pelanggan serta hubungan dengan mitra. Ketika pelanggan akhir memulai proses reverse logistics, biasanya diawali dengan pengecer. Seberapa baik pengecer mengelola proses reverse logistics dapat menentukan penghematan biaya serta kepuasan pelanggan dengan ritel tersebut. (Eric P. Jack et al., 2010)

\section{Anteseden Kemampuan Reverse Logistics}

Kemampuan reverse logistic meliputi keakuratan dan ketersediaan informasi yang digunakan, beserta proses reverse logistic dan informasi yang tepat waktu mengenai reverse logistic. Termasuk juga di dalamnya koneksi internal dan eksternal perusahaan serta informasi yang diperoleh dari koneksi tersebut. Kemampuan-kemampuan reverse logistic tersebut menampilkan sekumpulan informasi yang berkaitan dengan proses yang memungkinkan perusahaan untuk kedepannya lebih baik lagi mengelola aktivitas reverse logistic yang berkaitan dengan tujuan perusahaan untuk melakukan penghematan biaya. Reverse logistic mulai dijadikan sebagai perhatian utama oleh para manajer peritel karena biaya penyimpanan barang, kerugian penjualan, potensi untuk memperbaharui atau memperbaiki nilai produk, dan 


\section{Jurnal Manajemen Teori dan Terapan Tahun 8. No. 3, Desember 2015}

pentingnya hubungan antara konsumen dan mitra bisnis (Daugherty et al., 2005). Secara umum seorang konsumen memulai proses reverse logistic dengan pihak peritel. Seberapa baik seorang manajer peritel mampu melaksanakan proses reverse logistic pada akhirnya akan menentukan penghematan biaya yang dapat diperoleh, begitu juga dengan kepuasan yang diterima oleh konsumen dalam proses reverse logistic yang disediakan oleh peritel tersebut.

Dalam penelitiannya, Petersen dan Kumar berfokus pada perilaku pelanggan dalam membeli dan mereka mendefinisikan anteseden dan konsekuensi dari pengembalian produk melalui perspektif itu. Dalam penelitian tersebut, ditemukan beberapa faktor yang menghasilkan pengaruh pada kemampuan reverse logistics dan mencapai penghematan biaya dari perspektif pengecer. Penghematan biaya dari reverse logistics adalah tabungan yang didapatkan pengecer dari pelaksanaan proses reverse logistics dalam mendukung kebijakan pengembalian. Untuk memahami faktor-faktor apa yang mempengaruhi kemampuan reverse logistics dan penghematan biaya yang dihasilkan, kita mempertimbangkan anteseden tertentu yang spesifik. Hal ini ni termasuk unsur-unsur yang terkait dengan hubungan antara pengece dan pelanggan, unsur-unsur yang secara internal terkait dengan sumber daya perusahaan dalam reverse logistics dan kebijakan kontrak dengan pemasok. Berikut adalah beberapa faktor anteseden spesifik yang dipertimbangkan guna menciptakan penghematan biaya bagi peritel :

\section{- Customer Orientation atau Orientasi Kepada Konsumen}

Customer orientation atau orientasi terhadap konsumen adalah suatu keadaan yang menggambarkan sikap dari peritel dan aktivitas yang mereka lakukan dalam tujuan untuk memuaskan kebutuhan konsumen (Deshpande et al., 1993). Yang termasuk dalam orientasi terhadap konsumen adalah beberapa aspek yang tergambarkan di dalam alat ukur yang digunakan di dalam penelitian ini. Aspek-aspek tersebut meliputi pengembangan produk dan layanan yang didasarkan pada informasi-informasi yang berfokus pada konsumen (dalam artian perusahaan menggunakan informasi yang berbasis konsumen untuk mengembangkan produk atau layanan mereka), kemampuan yang dimiliki oleh perusahaan untuk memahami bagaimana konsumen menilai produk dan layanan yang disediakan oleh perusahaan, kompetisi yang dimiliki oleh perusahaan didasari oleh diferensiasi konsumen, dan mereka meyakini bahwa bisnis hadir untuk melayani konsumen. Orientasi terhadap konsumen secara tidak langsung menyiratkan bahwa sebuah organisasi atau perusahaan dapat mengembangkan keunggulan bersaing yang berkelanjutan dengan cara memahami dan mempertemukan konsumen dengan kebutuhan yang mereka butuhkan (Deshpande et al., 1993).

\section{- Customer Opportunism atau Perilaku Oportunis Konsumen}

Sikap oportunis akan muncul ketika seorang individu atau organisasi bertingkah sesuai dengan keinginan pribadinya atau didasari pada niatan pribadi (Williamson, 1975, p. 6). Sikap oportunis akan terlihat dengan jelas di dalam hubungan antara penjual dan pembeli, di mana salah satu pihak akan memanfaatkan hubungan yang terjalin untuk meningkatkan posisinya untuk mendatangkan keuntungan bagi dirinya sendiri dan membebankan pihak lain. Sikap oportunis merupakan sebuah halangan untuk sebuah perilaku yang kolaboratif atau halangan bagi sebuah kerjasama, di mana sebuah hubungan pastinya memerlukan adanya kepercayaan (Williamson, 1975, p. 26). Ketika perilaku oportunis muncul, hal itu akan menjadi sumber masalah yang dapat merusak kepercayaan yang ada (Williams, 2007).

Kebijakan retur sering kali dipandang oleh peritel sebagai sebuah biaya dalam menjalankan bisnisnya (Padmanabhan dan Png, 1997). Sebuah riset yang empiris mengindikasikan penerimaan peritel terhadap kebijakan reverse logistic yang bertujuan untuk menimilaisir ketidakpastian sesungguhnya menguntungkan pihak manufaktur (Padmanabhan dan Png, 1997), serta mengabaikan dampak pada hibungan kemitraan peritel. Perilaku oportunis konsumen barangkali dapat meningkatkan produk retur dan secara konsekuen meningkatkan biaya reverse logistic pula. Ketika konsumen sudah memutuskan akan berbelanja di mana dan memutuskan apa yang akan dibelinya, sebuah kebijakan retur akan menjadi hal yang penting bagi konsumen, dan di sisi lain konsumen akan mengambil keuntungan dari kebijakan retur yang disediakan oleh peritel.

\section{- Resource Commitment atau Komitmen Terhadap Sumber Daya}

Komitmen terhadap sumber daya terdiri dari sumber daya keuangan, teknik, dan manajerial perusahaan yang berkomitmen untuk kepentingan kemampuan reverse logistic. Setiap sumber daya tersebut diperlukan untuk mewujudkan dan menerapkan kemampuan reverse logistic. 


\section{Febriana Wurjaningrum Tuwanku Aria Auliandri}

Sumber daya keuangan, sesuai dengan kegunaannya, digunakan untuk membiayai prosesproses yang strategis, seperti reverse logistic. Selain itu, hal penting lainnya yang digunakan untuk mewujudkan reverse logistic adalah investasi.

Investasi dalam hal ini adalah berinvestasi pada bidang teknologi yang dapat membantu peritel untuk mengembangkan keunggulan bersaing yang berkelanjutan di mana teknologi yang digunakan adalah sesuatu yang sulit diduplikasi atau ditiru oleh peritel pesaing (Day, 1994; Srinivasan et al., 2002). Peritel yang memiliki dorongan untuk menginvestasikan sumber dayanya di bidang teknologi dianggap sebagai peritel yang memberikan perhatian khusus terhadap peningkatan kinerja dan layanan di dalam organisasinya, dan hal itu adalah baik (Zhou et al., 2005). Dengan berinvestasi di bidang teknologi, maka peritel dapat meningkatkan dan mengembangkan kemampuan reverse logistic dan hubungan atau proses yang terjadi antara peritel dan pemasok akan menjadi lebih efisien. Meskipun demikian, berinvestasi pada teknologi bukanlah satu-satunya cara untuk menciptakan kemampuan reverse logistic. Manajemen juga dituntut untuk menghabiskan waktu dan perhatian serta usaha untuk menentukan kemampuan reverse logistic yang dibutuhkan dengan tujuan untuk menciptakan kemampuan reverse logistic tersebut. Sedangkan sumber daya manajerial meliputi keterampilan atau kemampuan, pengalaman, pengetahuan, dan intelegensi karyawan di dalam perusahaan (Richey dan Wheeler, 2004).

\section{- Contractual Arrangements atau Perjanjian Kontrak}

Perjanjian kontrak adalah bagian dari sebuah proses sosialisasi dengan anggota mitra lainnya di dalam rantai pasok yang melibatkan hubungan yang sengaja diatur untuk menyelaraskan tujuan (Wathne dan Heide, 2000). Proses sosialisasi termasuk aktivitas yang dilakukan oleh peritel untuk mengembangkan perjanjian kontrak guna menciptakan hubungan yang kedepannya dapat menjadikan reverse logistic efektif. Mekanisme yang dimiliki oleh pemerintah harusnya bertujuan untuk menguatkan hubungan antara peritel dan pemasoknya. Guna meminimalisir resiko sikap oportunis dari mitra rantai pasoknya, perusahaan dapat menerapkan mekanisme pemerintah untuk mengurangi resiko untuk menerapkan kontrak formal yang ada.

Kontrak tersebut menjelaskan tujuan yang hendak dicapai, tanggung jawab, dan keuntungan dari hubungan dengan mitra di rantai pasok. Kontrak juga dapat berlaku sebagai dasar untuk menerapkan mekanisme pemerintah di masa mendatang yang tidak menentu. Kontrak dapat berkontribusi untuk meningkatkan kinerja di dalam hubungan kemitraan dengan tingkat ketidakpastian yang minimal (Cannon et al, 2000). Artinya, perjanjian kontrak yang telah dibuat tersebut mampu meningkatkan kinerja perusahaan dengan mitra-mitranya yang berada di dalam rantai pasok dengan jaminan yang lebih tinggi (tingkat ketidak-pastian minimal).

Orientasi pelanggan dan oportunisme pelanggan mencerminkan keinginan pengecer untuk berfokus pada pelanggan serta hubungan process-driven dengan pelanggan. Sementara, komitmen sumber daya mencerminkan sumber daya manajerial, teknis, dan keuangan yang diterapkan untuk membalikkan proses logistik. Pengaturan kontrak merepresentasikan back-end process dengan anggota saluran lain yang melibatkan pengembangan tujuan bersama. Akhirnya, kemampuan reverse logistics mewakili kemampuan internal dan proses sehingga perusahaan dapat melaksanakan reverse logistics secara efektif. (Eric P. Jack et al., 2010) Hipotesis yang diajukan pada penelitian ini adalah:

$\mathrm{H}_{1}$ : diduga terdapat hubungan positif customer orientation terhadap reverse logistics capabilities

$\mathrm{H}_{2}$ : diduga terdapat hubungan negatif customer opportunism terhadap reverse logistics capabilities

$\mathrm{H}_{3}$ : diduga terdapat hubungan positif resource commitment terhadap reverse logistics capabilities

$\mathrm{H}_{4}$ : diduga terdapat hubungan positif contractual aggrements terhadap reverse logistics capabilities

$\mathrm{H}_{5}$ : diduga terdapat hubungan positif reverse logistics capabilities terhadap reverse logistics cost saving 


\section{Jurnal Manajemen Teori dan Terapan Tahun 8. No. 3, Desember 2015}

\section{METODE PENELITIAN}

Penelitian ini menggunakan pendekatan metodologi kuantitatif dimana metode ini menitikberatkan pada pengujian hipotesa dengan alat analisa metode statistik dan menghasilkan kesimpulan mengenai hasil pengujian hipotesa tersebut yang dapat dijadikan sebagai penjelasan untuk saran pada objek penelitian. Asumsi-asumsi yang digunakan dalam penelitian ini adalah berupa variabel-variabel yang dapat diukur dan berguna untuk menjelaskan hubungan timbal balik (kausalitas) dimulai dengan hipotesa dan teori-teori.

Pengukuran variabel yang dilakukan di dalam penelitian ini diadopsi dari penelitian sebelumnya. Setiap indikator diukur dengan menggunakan skala Likert. Skala Likert didesain untuk menelaah seberapa kuat subjek setuju atau tidak setuju dengan pertanyaan pada skala lima poin (Sekaran, 2006: 31). Data primer merupakan data penelitian yang diperoleh secara langsung dari sumber asli (tidak melalui perantara) yang dapat berupa opini subyek (orang) secara individual atau kelompok, hasil observasi terhadap suatu benda, kejadian atau kegiatan (Indriantoro dan Supomo, 1999: 146-147). Pada penelitian ini, data primer diperoleh dari hasil wawancara melalui penyebaran kuesioner dan wawancara. Subyek dalam penelitian ini adalah perusahaan yang melakukan aktivitas reverse logistics dan sering berinteraksi secara langsung dengan para pemasoknya.

Metode yang digunakan dalam penentuan sampel pada penelitian ini adalah teknik purposive sampling, dimana peneliti hanya memilih responden yang memiliki karakteristik yang dimiliki oleh sampel serta dianggap memiliki kaitan erat dengan ciri-ciri atau sifat-sifat yang telah diketahui sebelumnya dan akan dapat membantu menjawab pertanyaan pada penelitian yang sedang dikerjakan (Prihatin dalam Prakoso, 2011). Sampel yang digunakan dalam penelitian ini adalah usaha kecil dan menengah (UKM) pada bidang ritel, penerbit, manufaktur, kerajinan tangan dan perdagangan obat (toko obat dan apotik) yang berlokasi di Surabaya, Malang, Singaraja dan Denpasar, yang memiliki struktur organisasi atau struktur kepengurusan yang tidak terlalu kompleks dan orang-orang atau pihak di dalam usaha kecil dan menengah yang secara langsung terlibat dalam proses reverse logistic dan mereka yang berinteraksi langsung dengan para pemasok. Jumlah responden yang merepresentasikan UKM yang menjadi unit analisa penelitian ini sebesar 140 usaha bisnis yang tersebar di empat kota tersebut. Di dalam kuesioner tersebut terdapat pertanyaan penyaring, yaitu pertanyaan yang bertujuan untuk mendapatkan responden yang diinginkan, yaitu pemilik UKM atau pihak yang bekerja di usaha kecil dan menengah yang berinteraksi langsung dengan proses reverse logistic dan yang berinteraksi langsung dengan pemasok, sehingga data yang diperoleh reliable dan valid.

Teknik yang analisis data yang digunakan adalah Path Analysis yang akan mempermudah untuk melihat hubungan kausalitas yang akan diuji. Pada diagram hubungan antar konstruk dinyatakan melalui anak panah. Anak panah lurus menunjukkan sebuah hubungan kausal yang langsung antara satu konstruk dengan konstruk yang lainnya.

\section{HASIL DAN PEMBAHASAN}

Pada bagian ini akan menjelaskan tentang karakteristik yang ada pada responden serta hasil jawaban responden yang berasal dari kuesioner terhadap masing-masing variabel yang ada di dalam penelitian ini. Untuk menggambarkan hasil jawaban yang berasal dari para responden melalui kuesioner yang telah disebar, peneliti akan mendeskripsikan atau menjelaskan secara terperinci nilai rata-rata pada masing-masing indikator yang membentuk variabel-variabel penelitian lalu kemudian mengelompokkannya berdasarkan pada interval kategori jawaban.

Variabel-variabel yang dirumuskan dalam penelitian ini merupakan faktor-faktor yang mempengaruhi atau antasedents pada reverse logistic capabilities pada usaha kecil dan menengah ataU UKM, dimana faktor-faktor tersebut antara lain adalah orientasi terhadap konsumen, sikap oportunis konsumen, komitmen sumber daya, serta perjanjian kontraktual. Faktor-faktor tersebut dianggap mampu mempengaruhi reverse logistic capabilities pada usaha kecil dan menengah atau UKM sehingga dapat menciptakan penghematan biaya. 


\section{Febriana Wurjaningrum Tuwanku Aria Auliandri}

\section{Pengujian Measurement Model (Outer Model)}

Outer model merupakan model yang menspesifikasi hubungan antara variabel laten dengan indikator-indikatornya atau bisa dikatakan bahwa outer model mendefinisikan bagaimana setiap indikator berhubungan dengan variabel latennya (Ghazali, 2011 : 22).

\section{Outer model dapat dianalisis dengan cara melihat beberapa hal yang diantaranya adalah}

\section{a. Convergent Validity}

Nilai konvergen mengukur besarnya loading factor untuk masing-masing konstruk. Loading factor diatas 0,70 sangat direkomendasikan, namun demikian loading factor $0.50-0.60$ masih dapat ditolerir sepanjang model masih dalam tahap pengembangan. Berikut ini akan ditampilkan nilai dari convergent validity untuk setiap variabelnya dalam penelitian ini. Berdasarkan nilai outer loading variabel orientasi konsumen, perilaku oportunis konsumen, komitmen terhadap sumber daya dan perjanjian kontraktual, maka diketahui bahwa semua indikator memiliki nilai outer loading lebih dari 0,5, sehingga indikator - indikator tersebut telah memenuhi validitas konvergen (convergent validity) artinya baik untuk mengukur variabel orientasi konsumen, perilaku oportunis konsumen, komitmen terhadap sumber daya dan perjanjian kontraktual. Berdasarkan nilai outer loading variabel kemampuan reverse logistic, diketahui bahwa semua indikator memiliki nilai outer loading lebih dari 0,5 , sehingga indikator indikator tersebut telah memenuhi validitas konvergen (convergent validity) artinya baik untuk mengukur variabel kemampuan reverse logistic. Berdasarkan nilai outer loading variabel penghematan biaya, diketahui bahwa semua indikator memiliki nilai outer loading lebih dari 0,5, sehingga indikator - indikator tersebut telah memenuhi validitas konvergen (convergent validity) artinya baik untuk mengukur variabel penghematan biaya.

\section{b. Discriminant Validity}

Selanjutnya akan dilakukan pengujian discriminant validity dengan melihat nilai akar average variance extracted (AVE) untuk setiap konstruk dan membandingkannya dengan korelasi antar konstruk. Model memiliki discriminant validity yang baik, jika akar AVE untuk setiap konstruk dalam model lebih tinggi dari korelasi antara konstruk tersebut dengan konstruk lainnya. Diketahui bahwa akar AVE pada setiap variabel memiliki nilai yang lebih besar dari pada nilai korelasi antar konstruk lainnya. Kemampuan reverse logistic yang memiliki nilai akar AVE lebih besar dari pada nilai korelasi konstruk kemampuan reverse logistic dengan komitmen terhadap sumber daya, perilaku oportunis konsumen, orientasi konsumen, penghematan biaya dan perjanjian kontraktual. Nilai akar AVE dari komitmen terhadap sumber daya memiliki nilai lebih besar dari pada nilai korelasi konstruk kemampuan reverse logistic, perilaku oportunis konsumen, orientasi konsumen, penghematan biaya dan perjanjian kontraktual. Nilai akar AVE dari perilaku oportunis konsumen lebih besar dari nilai korelasi konstruk kemampuan reverse logistic, komitmen terhadap sumber daya, orientasi konsumen, penghematan biaya dan perjanjian kontraktual. Beegitu juga nilai akar AVE untuk orientasi konsumen, penghematan biaya dan perjanjian kontraktual lebih besar daripada nilai korelasi konstruk variabel yang

lain. Dengan demikian dapat disimpulkan bahwa model variabel dalam penelitian ini memiliki discriminant validity yang baik.

\section{c. Composite Reliability}

Bagian ketiga pada outer model adalah menguji composite reliability. Composite reliability menguji nilai reliabilitas antara block indicator dari konstruk yang membentuknya. Nilai composite reliability dapat dikatakan baik bila nilainya lebih dari atau sama dengan 0,70 . Nilai composite reliability untuk tiap-tiap variabel dalam penelitian ini mempunyai nilai lebih dari 0,70. Variabel kemampuan reverse logistic mempunyai nilai 0,9749 , variabel komitmen terhadap sumber daya memiliki nilai sebesar 0,9104, variabel perilaku oportunis konsumen memiliki nilai 0,8507, variabel orientasi konsumen memiliki nilai 0,9746 , variabel penghematan biaya memiliki nilai 0,9451 dan variabel perjanjian kontraktual memiliki nilai 0,8510 . Oleh karena itu, nilai composite reliability untuk penelitian ini dapat dikatakan baik.

\section{Pengujian Inner Model}

Inner model merupakan model yang menspesifikasi hubungan antar variabel laten atau bisa juga dikatakan inner model menggambarkan hubungan antar variabel laten berdasarkan substantive theory (Ghazali, 2011 : 22). Berikut ini adalah nilai R-square yang ditampilkan oleh PLS untuk mengetahui hunbungan pengaruh pada variabel dalam penelitian ini. 
Tabel 1. Nilai R-Square

\begin{tabular}{|l|c|}
\hline & R Square \\
\hline $\begin{array}{l}\text { Kemampuan } \\
\text { Reverse Logistic }\end{array}$ & 0,8806 \\
\hline $\begin{array}{l}\text { Penghematan } \\
\text { Biaya }\end{array}$ & 0,7047 \\
\hline
\end{tabular}

Sumber: Data yang diolah

Dari tabel R-Square dapat dilihat bahwa variabel kemampuan reverse logistic memiliki nilai sebesar 0,8806. Hal ini menunjukkan bahwa variabel kemampuan reverse logistic dipengaruhi oleh komitmen terhadap sumber daya, perilaku oportunis konsumen, orientasi konsumen dan perjanjian kontraktual sebesar $88,06 \%$, sisanya mungkin dipengaruhi oleh faktor lain diluar penelitian. Sedangkan variabel penghematan biaya (cost savings reerse logistic) memiliki nilai 0,7047 . Nilai ini menunjukkan bahwa variabel penghematan biaya dipengaruhi oleh reverse logistic capabilities yang terdiri dari komitmen terhadap sumber daya, perilaku oportunis konsumen, orientasi konsumen, dan perjanjian kontraktual sebesar $70,47 \%$ dan sisanya dipengaruhi oleh faktor lain diluar penelitian ini.

\section{Pengujian Hipotesis}

Pengujian hipotesis dan hubungan antar variabel dapat dilihat dari hasil inner weight dan Path Coefficient (Mean, STDEV, T statistic), maka dapat disimpulkan interpretasi sebagai berikut:

1. Hipotesis pertama menyatakan bahwa terdapat hubungan positif antara orientasi terhadap konsumen dengan kemampuan reverse logistic. Jika melihat perhitungan dengan menggunakan software SmartPLS 2.0 maka dapat terlihat bahwa path variabel orientasi terhadap konsumen memiliki koefisien beta sebesar 0,6709 dengan nilai T-statistic sebesar 9,2805 yang berarti terdapat hubungan positif antara variabel orientasi terhadap konsumen terhadap variabel kemampuan reverse logistic. Dengan demikian hipotesis penelitian $\mathrm{HI}$ diterima atau bisa dikatakan didukung oleh data empiris.

2. Hipotesis kedua menyatakan bahwa terdapat hubungan negatif antara perilaku oportunis konsumen dengan kemampuan reverse logistic. Jika melihat perhitungan dengan menggunakan software SmartPLS 2.0 maka dapat terlihat bahwa path variabel perilaku oportunis konsumen memiliki koefisien beta sebesar -0,0417 dengan nilai T-statistic sebesar 0,8065 yang berarti terdapat hubungan negatif antara variabel perilaku oportunis konsumen terhadap variabel kemampuan reverse logistic. Dengan demikian hipotesis penelitian $\mathrm{H} 2$ tidak ditolak atau bisa dikatakan didukung oleh data empiris walaupun kurang signifikan.

3. Hipotesis ketiga menyatakan bahwa terdapat hubungan positif antara komitmen terhadap sumber daya dengan kemampuan reverse logistic. Jika melihat perhitungan dengan menggunakan software SmartPLS 2.0 maka dapat terlihat bahwa path variabel komitmen terhadap sumber daya memiliki koefisien beta sebesar 0,2260 dengan nilai T-statistic sebesar 3,3790 yang berarti terdapat hubungan positif antara variabel komitmen terhadap sumber daya terhadap variabel kemampuan reverse logistic. Dengan demikian, hipotesis penelitian $\mathrm{H} 3$ diterima atau bisa dikatakan didukung oleh data empiris.

4. Hipotesis keempat menyatakan bahwa terdapat hubungan positif antara perjanjian kontraktual dengan kemampuan reverse logistic. Jika melihat perhitungan dengan menggunakan software SmartPLS 2.0 maka dapat terlihat bahwa path variabel perjanjian kontraktual memiliki koefisien beta sebesar 0,1267 dengan nilai T-statistic sebesar 1,7493 yang berarti terdapat hubungan positif antara variabel perjanjian kontraktual terhadap variabel kemampuan reverse logistic. Dengan demikian, hipotesis penelitian $\mathrm{H} 4$ diterima atau bisa dikatakan didukung oleh data empiris.

5. Hipotesis kelima menyatakan bahwa terdapat hubungan positif antara kemampuan reverse logistic dengan penghematan biaya. Jika melihat perhitungan dengan menggunakan 


\section{Febriana Wurjaningrum \\ Tuwanku Aria Auliandri}

software SmartPLS 2.0 maka dapat terlihat bahwa path variabel kemampuan reverse logistic memiliki koefisien beta sebesar 0,8395 dengan nilai T-statistic sebesar 34,9217 yang berarti terdapat hubungan positif antara variabel kemampuan reverse logistic terhadap variabel penghematan biaya. Dengan demikian, hipotesis penelitian H5 diterima atau bisa dikatakan didukung oleh data empiris.

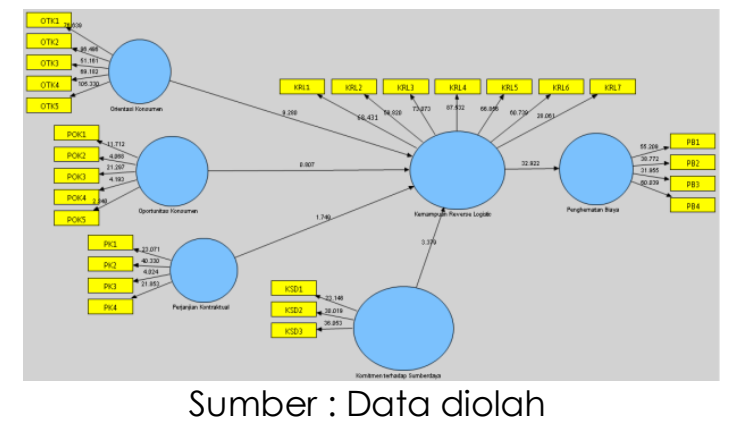

\section{Gambar 3. Hubungan Antara Beberapa Variabel Laten}

\section{KESIMPULAN}

Berdasarkan hasil analisis dan pengujian hipotesis pada penelitian ini, maka dapat diambil beberapa kesimpulan sebagai berikut:

1. Orientasi terhadap konsumen terbukti secara empiris memiliki hubungan yang positif dan signifikan terhadap kemampuan reverse logistic. Semakin tinggi orientasi usaha kecil dan menengah terhadap konsumennya, maka akan semakin tinggi pula kemampuan reverse logistic yang dimiliki.

2. Perilaku oportunis konsumen terbukti secara empiris memiliki hubungan yang negatif terhadap kemampuan reverse logistic. Semakin rendah perilaku oportunis konsumen, maka akan semakin tinggi kemampuan reverse logistic yang dimiliki oleh usaha kecil dan menengah walaupun hubungan tersebut tidak terlalu signifikan.

3. Komitmen terhadap sumber daya terbukti secara empiris memiliki hubungan yang positif dan signifikan terhadap kemampuan reverse logistic. Semakin tinggi komitmen usaha kecil dan menengah dalam menginvestasikan sumber dayanya dan semakin baik pengelolaannya demi menunjang kebijakan retur, maka akan semakin baik pula kemampuan reverse logisticnya.

4. Perjanjian kontraktual terbukti secara empiris memiliki hubungan yang positif terhadap kemampuan reverse logistic, walaupun hubungan tersebut tidak terlalu signifikan. Semakin baik perjanjian kontraktual atau perjanjian tertulis serta hubungan yang dibuat antara usaha kecil dan menengah dan pemasok, maka akan semakin baik kemampuan reverse logistic usaha kecil dan menengah.

5. Kemampuan reverse logistic terbukti secara empiris memiliki hubungan yang positif dan signifikan terhadap penghematan biaya. Semakin baik kemampuan reverse logistic yang dimiliki oleh usaha kecil dan menengah maka akan semakin kuat pula kemampuan usaha kecil dan menengah dalam melakukan penghematan biaya.

\section{REFERENSI}

Bernon. M., Cullen. J., and Rossi. S. (2011). "Reverse Logistic a Call and Grounding Framework for Research". International Journal Of Physical Distribution and logistics Management. Vol 41. Pp 484-510

Chopra, Sunil \& Peter Meindl. 2007. Supply Chain Management: Strategy, Planning \& Operations, 3rd Edition. Pearson Prentice Hall.

Christopher, Martin, 2005, Logistic \& Supply Chain Management 3rd edition, Pearson, Britain.

Easton, R. and Zhang, T.B. (2003), Nine Opportunities to Achieve Supply Chain Excellence in Asia, Accenture, January. 


\section{Jurnal Manajemen Teori dan Terapan Tahun 8. No. 3, Desember 2015}

Ghiani, Gianpolo., 2003, Introduction to Logistic System Planning and Control, Mc Graw Hill Book Company, New York.

Ghozali, Imam. 2011. "Structural Equation Modeling Metode Alternatif dengan Partial Least Square (PLS"). Edisi Kedua. Semarang : Badan Penerbit - Undip.

Green, Kenneth W., et. al. 2008. Impact of logistics performance on organizational performance. Supply Chain Management: An International Journal. Vol 13, Number 4, pp. 317-327

Hair, J. F., Anderson, R. E., Tatham, R. L., and Black, W. C. (2008). Multivariate Data Analysis. Sixth Edition. Prentice-Hall, Inc. New Jersey.

Hendayani, Ratih, (2011), "Mari Berkenalan dengan Manajemen Logistik", cetakan kesatu, Penerbit Alfabeta

Jack, Erick P., Thomas L. Powers, Lauren Skinner. 2010. Reverse Logistics Capabilities: Antecedents and Cost Savings. International Journal of Physical Distribution \& Logistics Management, Vol. 40 Iss: 3 pp. $228-246$.

Petersen, A.J. and Kumar, V. (2009), "Are product returns a necessary evil? Antecedents and consequences", Journal of Marketing, Vol. 73 No. 5, pp. 35-51.

Pujawan, I Nyoman. Mahendrawathi Er. 2005. Supply Chain Management Edisi Pertama. Penerbit Guna Widya. Surabaya.

Richey, R.G., Chen, H., Genchev, S.E. and Daugherty, P.J. (2005), "Developing effective reverse logistics programs", Industrial Marketing Management, Vol. 34, pp. 830-40.

Sangam, Vijay. 2010. Reverse Logistics. (http://vijaysangamworld.wordpress.com, diakses 12 Desember 2012)

Simchi-Levi, David, (2003), "Designing and Managing the Supply Chain: Concepts, Strategies, and Case Studies"

Soto Zuluaga, Juan Pablo, (2005)."Reverse Logistic : Model and Application".

Stock, J. and Mulki, J.P. (2009), "Product returns processing: an examination of practices of manufacturers, wholesalers/distributors, and retailers", Journal of Business Logistics, Vol. 30 No. 1, pp. 33-63.

Stock, J., Speh, T. and Shear, H. (2006), "Managing product returns for competitive advantage", MIT Sloan Management Review, Fall, pp. 57-62.

Sutapa. I Nyoman (2009). "Kebutuhan Sumber Daya dan Kapabilitas Dalam Menanganai Reverse Logistic", Jurusan Teknik Industri. Vol 11. Pp 163-173

Trkman, Peter, et.al. 2006. Measurement of Supply Chain Integration Benefits. Interdisciplinary Journal of Information, Knowledge, and Management Volume 1.

Vanderstoep, Scott W. and Diedre D. Johnston. 2009. Research Methods for Everyday Life: Blending Qualitative and Quantitative Approaches. Jossey-Bass. San Francisco.

Verma, Ajay and Nitin Seth. 2010. Achieving Supply Chain Competitiveness: Some Critical Issues. International Journal of Science and Technology, Vol. 2(11), pp. 6209 - 6213.

V. Ravi, Ravi Shankar, (2006),"Reverse logistics operations in paper industry: a case study", Journal of Advances in Management Research, Vol. 3 Iss: 2 pp. 88 - 94

Williams, M. (2007), "Building genuine trust through interpersonal emotion management:

a threat regulation model of trust and collaboration across boundaries", Academy of Management Review, Vol. 32 No. 2, pp. 595-621.

Yen-Chun Jim Wu, Wei-Ping Cheng, (2006), "Reverse logistics in the publishing industry: China, Hong Kong, and Taiwan", International Journal of Physical Distribution \& Logistics Management, Vol. 36 Iss: 7 pp. $507-523$ 